\title{
O SUPREMO TRIBUNAL FEDERAL E A DISCIPLINA DA EFICÁCIA DAS MEDIDAS PROVISÓRIAS NÃO CONVERTIDAS
}

\author{
EDILSON PEREIRA NOBRE JÚNIOR*
}

O Constituinte de 1988, mantendo tradição inaugurada em 1891, reservou ao Supremo Tribunal Federal papel de destaque na organização judiciária patrial, consistente na missão de guardião da autoridade, inteireza positiva e uniformidade interpretativa da Lei Máxima.

Essa afirmativa é corroborada pelo art. 102, caput, do Texto Magno, ao declarar competir àquele, de maneira precípua, a vigilância da Constituição, cabendo-lhe, entre outras competências, as de julgar: a) a ação direta de inconstitucionalidade de lei ou ato normativo federal ou estadual; b) a ação declaratória de constitucionalidade de lei ou ato normativo federal,- c) mandado de injunção, quando a norma indispensável à eficácia de direito ou liberdade constitucional for da alçada do Presidente da República, do Congresso Nacional, da Câmara dos Deputados, do Senado Federal, do Tribunal de Contas da União, dos Tribunais Superiores, ou do próprio Supremo Tribunal Federal, d) recurso extraordinário, desde que a decisão recorrida contrarie dispositivo da Constituição, declare a inconstitucionalidade de tratado ou lei federal, ou que julgue válida lei ou ato de governo local, contestado em face da Constituição; e) a argüição de descumprimento de preceito fundamental, disciplinada, recentemente, pela Lei 9.882, de 03.12.99. Fora do largo elenco do art. 102 da CF, colhe-se no art. $103, \S 2^{\circ}$, do mesmo diploma, a competência para processar e julgar a ação declaratória de inconstitucionalidade por omissão.

Daí se pode, com facilidade, perceber que, conquanto possa não se admitir a existência de efeito vinculante às decisões do Supremo Tribunal Federal em matéria de interpretação da Lei Maior, salvo a explícita previsão constitucional no particular da ação declaratória de constitucionalidade, não se pode deixar de constatar a circunstância de que, na prática, enorme influência tais deliberações exercem sobre os julgamentos dos demais juízes e tribunais.

* Professor da UFRN. Professor da Especialização em Direito Administrativo da UFPE e Mestre em Direito pela UFPE. Juiz Federal. 
Tanto é assim que, tão logo promulgada a atual Lei Fundamental, o Min. Sydney Sanches, comentando, em estudo doutrinário, as novas atribuições confiadas ao Pretório Excelso, destacou: “a função precípua de guarda da Constituição confere ao Supremo Tribunal Federal posição de enorme responsabilidade e importância na implantação e preservação da nova ordem constitucional" !

Feita essa advertência inicial, segue-se que, na Constituição promulgada em 1988, dentre os inúmeros dispositivos que vêm ensejando maiores discussões, está o seu art. 62, ao traçar competência legislativa especial em prol do chefe do Poder Executivo, consistente na edição de medidas provisórias.

Acolheu-se, assim, instituto que habilita o Governo a legislar por atribuição própria, sem prévio consentimento do Parlamento ${ }^{2}$, cuja intervenção fiscalizadora se faz posteriormente, a exemplo do que ocorre, em virtude da necessidade inarredável de ação legislativa rápida, vivenciada nos tempos hodiernos, com vários modelos hauridos no constitucionalismo contemporâneo, a saber: os arts. 77 da Constituição italiana de 1947 (decreto-legge), 81 da Constituição alemã de 1949 (estado de necessidade legislativa), 16 e 34 da Constituição da França de 1958 (poderes extraordinários do Presidente da República e o regulamento autônomo), 44 da Constituição da Grécia de 1975 (adoção de atos legislativos em circunstâncias excepcionais de necessidade extremadamente urgente e imprevista), $198^{\circ}$ da Constituição de Portugal de 1976 (decreto-lei), 86 da Constituição hispânica de 1978 (decreto-ley), 99, inciso 3, da Constituição da Nação Argentina de 1853, com a reforma de 1994 (decretos de necesidad y urgencia) e, mais recentemente, os arts. 101 da Constituição da Croácia (decretos com força de lei), 108 da Constituição da Eslovênia de 1991 (decretos com força de lei), 114.4 da Constituição da Romênia de 1991 (ordenanças de urgência), 109 da Constituição da Estônia (decretos presidenciais) e 85 da Lituânia (decreto-lei), ambas de 1992.

É sabido que, na praxe, o Congresso Nacional tem, com frequiência, se omitido no exercício do relevante controle que lhe outorgara o Constituinte, pois não vem convertendo, no escasso trintídio constitucional, as medidas provisórias editadas pelo Presidente da República, ocasionando o fenômeno que se convencionou denominar de reedição, de admissibilidade tranqüila no Supremo Tribunal Federal. ${ }^{3}$

A não conversão em lei tem como efeito implicar na perda da vigência da medida provisória desde a sua edição (ex tunc), conforme texto expresso do art. 62, parágrafo único, primeira parte, da CF, no que colhera inspiração no art. 77.3 da Constituição italiana.

1 O Supremo Tribunal Federal na Nova Constituição. In: A Constituição Brasileira 1988 Interpretações. 1. ed. Rio de Janeiro: Forense Universitária, p. 214.

2 A legislação governamental por competência constitucional específica não constitui novidade em nosso sistema jurídico, como se pode relembrar do decreto-lei das Constituiçōes de 1937 (arts. 13 e 14) e de 1969 (art. 55), sem contar os Atos Institucionais n 2 (art. 30) e 5 (art. 2).

3 ADIN 293-7, Pleno. mv, rel. Min. Celso de Melo, DJU de 16-04-93; ADIN 1.660-SE, Pleno, niv. rel, desig. Min. Nélson Jobim, DIU de 07-12-2000, p. 04; ADIN 1.610-5, Pleno, mv, rel. Min. Sydney Sanches, DJU de 05/12/97, p. 63.148; ADIN 1.398-1 — DF, Pleno, rel. Min. Carlos Veloso. DJU 27/06/97. 
Não se pode descartar haverem as normas, contidas na medida não convertida, logrado aplicação a numerosos casos concretos durante a sua efêmera vigência. Qual será, então, a sorte dos atos realizados com base na referida norma? Reputar-se-ão írritos ou válidos? A princípio, a primeira alternativa se impõe. A perda de eficácia ex tunc da medida provisória desemboca, como corolário lógico, na cessação, também retrooperante, das suas aplicações. ${ }^{4}$

Para uma resposta completa, inconcebível, porém, olvidar-se o temperamento imposto pela parte final do parágrafo único do art. 62, preceituando caber ao Congresso Nacional a disciplina das relações jurídicas, decorrentes da temporária aplicação das medidas provisórias não transmudadas em lei. Estatuiu o Constituinte, conforme se pode ver sem sombra de dúvidas, a solução para o problema calcada no instituto da convaliḍação dos efeitos das medidas provisórias não convertidas.

Percebe-se, portanto, que a melhor exegese do art. 62, parágrafo único, parte final da CF, é aquela a recomendar, ante a não-validade das normas da medida não convertida, a qualidade de inválidos aos atos perpetrados no decorrer de sua aplicação. No entanto, permite-se ao Congresso Nacional regular - e com força retroativa, advirta-se - as consequiências da medida provisória, reconhecendo-lhe, no todo ou em parte, validade. Pode, assim, o Legislativo, conferir validez a atos praticados com fulcro em medida provisória não aprovada ${ }^{5}$.

Trata-se de previsão expressa de retroatividade pela própria Constituição, a ressalvar apenas as regras que consagrara nos seus arts, $5^{\circ}$, XXXVI, XL e 150 , III, a, desde que a base fática indispensável à sua aplicação preceda à convalidação. Para

4 Mais simples a sistemática projetada para o extinto decreto-lei, haja vista que o art. $55, \S 2^{\circ}$, da Lei Maior revogada, era expresso em enfatizar que a rejeição daquele não implicará na nulidade dos atos praticados durante a sua vigência Assim também em na península itálica, com 0 art. $3^{\circ} \mathrm{da}$ famigerada Lei 100 , de 1926, prevendo que não convertido o decreto-legge no prazo marcado, que se prolongava até dois anos, a cessação dos seus efeitos se dava ex nunc.

5 No sistema jurídico italiano, prevalece a convicção de competir ao Parlamento disciplinar ou não tais relações jurídicas (Sentenze 86/1966, 144/1972 e 185/1981; recentemente, esse pendor constou de forma cristalina da Sentenza 84/1996, a ser doravante mencionada), não existindo obrigatoriedade para fazê-lo. Da mesma forma, caso as Câmaras decidam fazer uso de tal competência, não estão sujeitas a qualquer prazo de preclusão, podendo, como bem anota Alessandro Pizzorusso (Lecciones de Derecho Constitucional. Madri: Centro de Estudios; Constitucionales, 1984. p. 275-276) fazê-lo em procedimento singularizado, em relação à lei de conversão, ou no corpo desta, ou ainda através da lei de conversão de outro decreto-legge, conforme ressaltou a Corte Constitucional na Sentenza 249, de 28 de maio de 1996, relatada pelo Juiz Enzo Cheli (disponível em www.giurcost.org/decisioni. Acesso em 09-07-01). No Brasil, a doutrina se biparte, havendo alguns autores que, à consideração de ser inconstitucional a omissão do Congresso Nacional, advogam a possibilidade, para combatê-la, de ajuizamento de mandado de injunção ou de ação declaratória de inconstitucionalidade por omissão, como é o caso de Ivo Dantas (Aspectos jurídicos das medidas provisórias. 3. ed. Brasília: Brasília Jurídica, 1997. p. 85) e Clèmerson Merlin Clève (Atividade legislativa do Poder Executivo no Estado Contemporâneo e na Constituição de 1988. São Paulo: RT. 1993. p. 173), enquanto outros propendem à liberdade da avaliação política de agir do Parlamento, servindo de exemplo José Afonso da Silva, embora este ressalve possa o Judiciário ser convocado a examinar o assunto a teor do disposto no art. $5^{\circ}, \mathrm{XXXV}$, se houver lesão de direito de outrem (Curso de direito constitucional positivo. 8. Ed. São Paulo: Malheiros, 1992. p. 465). 
uma melhor compreensão, esclareça-se que a configuração de ato jurídico perfeito, direito adquirido, ou coisa julgada, anteriores à vigência da medida provisória não convertida, mas cujos efeitos foram convalidados pela atividade do Congresso Nacional, orienta-se pela nota da intangibilidade. Caso o fato gerador daqueles institutos se situe em instante posterior à convalidação, deverá aplicar-se a disciplina introduzida pela medida provisória cuja eficácia fora convalidada, não sendo a hipótese de prestigiar-se a segurança jurídica.

O fenômeno, originário do ordenamento constitucional italiano, foi bem retratado através de Federico Sorrentino, ao expressamente mencionar a possibilidade de retroação, inclusive com a possibilidade de não se proceder ao respeito aos correspondentes limites constitucionais. Diz o autor: "A falta de conversão autoriza, como se viu, as Câmaras a disciplinar com lei as relações jurídicas surgidas com base no decreto não convertido, consentindo aquelas em assim superar eventuais limites à retroatividade das leis e, sobretudo, em derrogar o princípio da decadência retroativa dos decretos não convertidos, fazendo seguras as relações que tal decadência renderia inválida"6. Mais à frente, remata: 'Na praxe o legislador faz uso deste poder com uma fórmula geral de sanatória de todos os atos e relações conseqüentes ao decreto não convertido: isto equivale a uma confirmação do decreto pelo período no qual aquele esteve em vigor, com todas as consequiências que podem provir em sede aplicativa" 7 .

O magistério do referido autor, deduzido do exame da ordem jurídica italiana, mas que guarda, nesse ponto, sensivel similitude com a nossa, longe está a induzir a autorização para que, nas reiterações, as futuras edições de decreti-legge tragam a cláusula de que ficam convalidadas as relações jurídicas surgidas com fundamento no decreto-legge não convertido, haja vista que o art. 77.3 da Constituição Italiana atribui tal competência à lei.

A semelhança dos sistemas, antes apontada, reside em que o art, 62, parágrafo único, parte final, da CF, é expresso, para não dizer enfático, em ditar que, não convertida a medida provisória em lei, os efeitos desta decorrente serão disciplinados

6 "La mancata conversione, autorizza, como si è visto, le Camere a disciplinare con legge $i$ rapporti giuridici sorti sulla base del decreto non convertito, consentendo loro di superare così eventuali limiti alla retroattività delle leggi e, soprattutto, di derogare al principio della decadenza retroattiva dei decreti non convertiti. facendo, salvi rapporti che tale decadenza renderebbe invalidi" (II decreto legge non convertito. In: BAUDREZ, Maryse et alli. I decreti-legge non convertiti. Milano, Giuffrè. 1996. p. 82).

7 "Nella prassi il legislatore fa uso di questo potere con una formula generale di sanatoria di tutti gli atti $e$ i rapporti conseguenti al decreto non convertito: ciò che equivale ad una conferma del decreto per il periodo in cui esso é stato in vigore, con tutte le conseguenze che ne possono discendere in sede applicativa". (ibidem, p. 82). A Corte de Cassação (Sentenze 4.262, de 06-10-77 e 3.034, de 25-05-79) - mostra-nos Giovanni Pitruzzzella (La legge di conversione del decretolegge. Pádua: CEDAM, 1989. p. 330) - no particular das relações tributárias, manifesta-se que a incidência retroativa da lei de sanatória somente poderá atingir situações de fato, geradoras do crédito tributário, caso sucedidas durante a vigência do decreto-legge não convertido. O raciocínio jurisprudencial peninsular é idêntico ao que expusemos no parágrafo anterior ao objeto desta nota. 
pelo Congresso Nacional. Isso é o suficiente para excluir, nesse campo, a atividade isolada do Chefe do Poder Executivo.

O Supremo Tribunal Federal, inicialmente, propendeu a esse entendimento, salientando o despropósito do Presidente da República em editar medida provisória, com vistas a prover a competência do art. 62, parágrafo único, parte final, da Lei Básica. Expresso, a esse respeito, o despacho, da lavra do Min. Celso de Mello, ao negar seguimento à ADIN $365-8 / 600^{8}$, ratificado em sede de agravo regimental ${ }^{9}$.

É sabido que, posteriormente, o STF, em várias oportunidades, como se pode exemplificar no julgamento da ADIN 1.660-SE, ao reputar válida a MP 560/94 e suas reedições, que instituíram a alíquota de $12 \%$ para a contribuição previdenciária dos servidores públicos federais, louvou-se no entendimento de que referido instrumento normativo, renovado, sucessiva e tempestivamente, manteve, por isso, a eficácia de lei.

Na motivação exarada no julgado, acima referenciado, não é abordado o tema da convalidação dos efeitos das anteriores medidas provisórias não convertidas. A discussão teve como foco a possibilidade ou não de reedição.

Não obstante, em recente manifestação na ADINMC 2.251-DF ${ }^{10}$, assestada contra o art. 14 da MP 1.984-19, que convalidara os atos praticados com base na MP 1.984 -18, o Plenário do Supremo Tribunal Federal, vencidos os Ministros Marco Aurélio e Celso de Mello, entendeu, já agora enfrentando o tema, não ofender a competência do Poder Legislativo a circunstância de medida provisória convalidar a eficácia produzida por medida provisória não convertida. Uma abordagem crítica desse julgado configurará o objeto deste estudo.

8 DJU de 05-10-90, p. 10.717. Cuidava-se a hipótese de impugnação, pela Confederação Nacional da Indústria, da Instrução Normativa 102/90, editada pela Secretaria da Receita Federal, apontada como instituidora de novas hipóteses de incidência do IOF. Em decisão monocrática, entendeu-se incabível a ação direta de inconstitucionalidade, uma vez que o ato regulamentar em causa, em estabelecendo interpretação não autorizada à MP 195/90, não traduzia situação de conflito constitucional, mas de ilegalidade. Atento à circunstância fática de que o art. 10 da NT 212/90, dispondo sobre o mesmo assunto, inserira cláusula de convalidação das MP's $195 / 90$ e 200/90, o relator, no referido despacho, tecera breve consideração sobre essa questão, a despeito de não constituir a finalidade primordial do feito em exame: "A disciplina das relações jurídicas formadas com base no ato cautelar não convertido em lei constitui obrigação indeclinável do Congresso Nacional, que deverá regrá-las mediante procedimento legislativo adequado. $O$ exercício dessa prerrogativa congressional deriva, fundamentalmente, de um principio essencial de nosso sistema constitucional: o princípio da reserva de competência do Congresso Nacional. A disciplina de que trata o parágrafo único do art. 62 da Carta Política tem, por isso mesmo, na lei formal, de exclusiva atribuição do Congresso, seu instrumento jurídico idôneo, sendo relevante observar que, de seu processo de formação, co-participará o Presidente da República, pelo exercício da competência constitucional de que dispōe para sancionar ou vetar os projetos de lei aprovados pelo Legislativo".

9 AGRADI 365 - DF. Plenário, ac. un., rel. Min. Celso de Mello, DJU de 15.03.91, p. 2.645.

10 Plenário, mv, rel. Min. Sydney Sanches, DJU 23.08.2000, Informativo STF n'. 199. Considerando-se que, ao instante em que escrito este trabalho, a ementa do julgado ainda não tinha sido publicada, com a disponibilização dos votos predominantes e minoritários, o nosso conhecimento da doutrina naquele firmada se limita a resenha contida em órgão de divulgação da Excelsa Corte. 
É certo que, aproximadamente três meses depois, no desate do RE 254.818-PR ${ }^{11}$ o Supremo Tribunal Federal manteve decisão do Tribunal Regional da $4^{a}$ Região, que aplicara o beneficio de suspensão da ação penal pela suposta prática do delito do art. 95, $d$, da Lei 8.212/91, previsto na Medida Provisória 1.571 - 6/97, mas suprimido pela Medida Provisória 1.571-8.197, em virtude da convalidação dos efeitos daquela pela Lei 9.639/98, tendo o relator, ao ensejo da confirmação de seu voto, feito remissão elogiosa ao voto-vista do Ministro Moreira Alves, ao reputar válida tal cláusula, contida na lei de conversão, a qual seria, no particular, insuscetível de veto, por a matéria ser específica de decreto legislativo.

Da decisão no RE 254.818-PR penso não haver decorrido a alteração do ponto de vista fixado na também recente ADINMC 2.251-DF, porquanto no voto do relator, Min. Sepúlveda Pertence, disponibilizado no Informativo STF $n^{\circ} 220$, haja vista a não publicação da respectiva ementa, não fora reativado o debate em torno da violação do art. 62 , parágrafo único, da $\mathrm{CF}$, pela circunstância de a convalidação da eficácia dos atos de medida provisória não convertida advir de medida provisória posterior.

Abstraindo-se a quizília doutrinária sobre se a espécie normativa adequada para se concretizar o fim visado pelo art. 62, parágrafo único, parte final, da $\mathrm{CF}$, é a lei ou o decreto legislativo ${ }^{12}$, porquanto ambos são produtos da atividade legislativa do Congresso Nacional (e assim, em ambas hipóteses, eventual inconstitucionalidade formal seria facilmente contornada), é de concluir-se, sem tergiversação, que o dispositivo constitucional, ao contrário do respeitável ponto de vista do Supremo Tribunal Federal ADINMC 2.251-DF, dispôs pela não admissibilidade da medida provisória, vista esta emanar, como frisado linhas retro, da atuação exclusiva do Poder Executivo.

É induvidoso que o Supremo Tribunal Federal, na sua missão de guardião da Lei Magna, possa adaptar o conteúdo das normas constitucionais às mudanças na sociedade, sem que para tanto seja necessário alterar o texto daquelas. No entanto, essa operação exegética, denominada mutação constitucional, não pode ser arbitrária. Não há de esconder limites, entre os quais, pondera Hesse ${ }^{13}$, o de que resulta

11 Pleno, ac. un., rel. Min. Sepúlveda Pertence, julg. em 08-11-2010, Informativo STF n 209.

12 Favoráveis à lei para o desempenho da competência do art. 62, parágrafo único, parte final, da Lei Básica, podemos citar: Ivo Dantas (Aspectos jurídicos das medidas provisórias. 3. ed. Brasília: Brasília Jurídica, 1997. p. 85; Nagib Slaibi Filho (Anotações à Constituição de 1988 - aspectos fundamentais. Rio de Janeiro, Forense, 1989. p. 346); José Afonso da Silva (Curso de direito constitucional positivo. 8. ed. São Paulo: Malheiros, 1992, p. 465) -, Clèmerson Merlin Clève (Atividade Legislativa do Poder Executivo no Estado Contemporâneo e na Constituição 1988. São Paulo: RT, 1993. p. 173). Diversamente, para Alexandre de Moraes (Direito constitucional. 8. ed. São Paulo: Atlas, 1999. p. 536), o veículo apropriado será o decreto legislativo. Esta fora a opção, a nosso ver acertada, da Resolução $01 / 89$ do Congresso Nacional (arts. $6^{\circ}$, parágrafo único, $7^{\circ}$, II e 17). Almejando pôr cobro à discussão, a PEC 472 - C, de 1997, projeta o acréscimo de $\S 1^{\circ}$ ao art 62, conferindo tal mister ao decreto legislativo.

13 Constitución y derecho constitucional. In: BENDA, Ernesto et alii. Manual de derecho constitucional, Madri: Marcial Pons, 1996. p. 10. Luís Roberto Baroso (Interpretação e aplicação da 
inadmissível uma interpretação diferente dos enunciados magnos em aberta contradição com o texto da Lei Fundamental. Admitir-se que a disciplina das relações jurídicas surgidas com base em medida provisória, não transmudada em lei no prazo de 30 dias, seja realizada por outra medida provisória, é o mesmo que desconstituir a cláusula contida no art. 62, parágrafo único, segunda parte, da $\mathrm{CF}$, quando enuncia, sem deixar a mínima margem de dúvida, dever "o Congresso Nacional disciplinar as relações jurídicas delas decorrentes".

Indispensável, mais uma vez, o recurso ao sistema jurídico italiano, cuja prática do decreto-legge, fonte informativa da medida provisória, recua há aproximadamente 54 anos, sem contar as decretações de urgência emanadas com autorização implícita do Estatuto Albertino de 1848 e sob os auspícios da Lei 100, de 1926, produto do regime fascista ${ }^{14}$. E não é só. $\mathrm{O}$ apelo ao modelo italiano torna-se obrigatório quando se constata - não é demasiado tomar a repetir - que o art. 77.3, da Lei Maior da Itália de 1947, perfilha idêntica solução à preconizada pelo art. 62, parágrafo único, parte final, da $\mathrm{CF}$, ao dizer competir às Câmaras tal regulação. A única diferença - a nosso ver, desinfluente para o questionamento proposto pela inicial - é que o constituinte peninsular houve por bem indicar a lei como o instrumento posto à mão do Parlamento para dispor sobre as relações surgidas no espaço de vigência de decreto-legge não convertido.

Atenta à hipótese, que se tornou frequiente na Itália, no interregno antecedente à Sentenza 360 , de 17 de outubro de $1996^{15}$, onde os sucessivos decretos leis, embora sem lograr conversão em lei, declaravam válidos, para o passado, os efeitos dos precedentes, de que eram reprodução, a doutrina, sem maiores considerações, ante a pacificidade que deveria ostentar o tema, reputara impossível que um decreto-legge dispusesse sobre os efeitos de outro decreto-legge, mantendo-os hígidos ${ }^{16}$. Nesse

Constituição. 3. ed. São Paulo: Saraiva, 1999. p. 146), ao referir-se ao fenômeno como interpretação evolutiva, adverte que esta há de sofrer limitações, ora porque a abertura da linguagem constitucional e a polissemia de seus termos não são absolutas, estancando-se diante de significados mínimos, ora em virtude dos princípios fundamentais do sistema serem intangíveis, de sorte que as alteraçōes informais introduzidas pela via hermenêutica não poderão contravir os programas constitucionais. Idem Arnaldo Penteado Laudísio (Controle de constitucionalidade e interpretação constitucional. Revista Ajufe, São Paulo, v. 45, p. 46, abr./jun., 1995), ao suster que a exegese deve encontrar divisas, a fim de que não seja desnaturado o texto, a intenção e a genética constitucional. Acrescente-se ainda que o próprio Supremo Tribunal Federal, na Representação de Inconstitucionalidade 1.417-7 (Pleno, ac. un., rel. Min. Moreira Alves, DJU de 1.417-7, p. 8.397), deixou evidente não caber a aplicação do princípio da interpretação conforme à Constituição quando a única exegese possível para harmonizar a norma impugnada com a Lei Maior contrariar o sentido inequívoco desta.

14 Em retrospectiva, Biscaretti di Ruffia (Diritto Costituzionale. 15. ed. Nápoles: Jovene Editore, 1989. p. 569) aponta, no solo itálico, o pioneirismo para o decreto de 27 de maio de 1948.

15 Rel. Juiz Enzo Cheli, disponível em www.giurcost.org/decisioni. Acesso em 08-02-01. Aludida decisão que, segundo Maryse Baudrez (Décrets-lois réitérés en Italie: l'exaspération mesurée de la Cour constitutionnelle. Revie Française de Droit Constitucionnel, $\mathrm{n}^{\circ} 32$, p. 752, 1997). consubstanciou lídima "bomba" jurisprudencial, ao interditar a reiteração do decreto-legge.

16 Entre as diversas hipóteses de utilização indevida do decreto-legge, listadas por Franco Modug- 
ponto, aliás, clara é a lição de Vezio Crisafulli que, em comentários à Constituição de 1947, afirma: "Em verdade, a circunstância - agora apontada no texto - de que o sujeito lexical da disposição da última parte do art. 77 da Constituição são apenas as Câmaras, constitui um forte indício da inconstitucionalidade da convalidação, disposta mediante um novo decreto, do efeito produzido por decreto-lei não convertido" 17 .

Vittorio di Ciolo, fazendo remissão à Lei 400/88, que traça procedimentos a serem observados na emissão de decreti-legge, afirma: "É conhecido que o art. 15 da Lei n. ${ }^{\circ} 400 / 1988$ estabelece, além disso, que o Governo não pode, mediante decreto-lei, regular as relações jurídicas surgidas com base em decretos não convertidos (é que o último inciso do art. 77 da Constituição confia às Câmaras tal tarefa: também se reconheceu que uma aplicação lenta da previsão constitucional pode determinar efeitos danosos para os sujeitos que, em obséquio à lei, tenham-se submetido às disposições do decreto)" ${ }^{18}$.

Alfonso Celloto, por sua vez, é peremptório: "Igualmente pacífica aparece a preclusão para os decretos de sanar os efeitos surgidos com base em decretos precedentes não convertidos, ante a explícita reserva às "Camere (de) regular com $l e i$ as relações jurídicas surgidas com base nos decretos-lei não convertidos" ${ }^{19}$.

Não pára por aí. Giovanni Pitruzzella, a propósito de comentar o art. 77.3, parte final, da Lei Maior itálica, acentuou, sem dar azo a qualquer dúvida: "A disposição em exame pode ser entendida no sentido que proíbe que a disciplina das relações

no, em trabalho realizado em co-autoria com Alfonso Celloto (Rimedi all' abuso del decreto-legge.

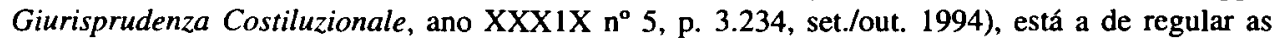
relações jurídicas surgidas com base em decreto não convertido, exemplificada, dentre outras situações, pelo decreto-legge 457, de 24 de novembro de 1992 e de suas reiterações (decreto-legge 17, de 23 de janeiro de 1993, e 80, de 25 de março de 1993), os quais, tenderam a convalidar os efeitos do art. 20 do decreto-legge 195, de 01 de novembro de 1992, 274, de 30 de abril de 1992, e 325 , de 01 de julho de 1992 .

17 "Per la verità, la circostanza - dianzi accennata nel testo - che, il soggetto lessicale della disposizione dell'ultima parte dell'art. 77 Cost. siano proprio (le Camere) costituisce un indizio assai forte dell'inconstítuzionalitá della convalida di effetti prodotti da un decreto-legge non convertito, disposta con un nuovo decreto". (Lezioni di Diritto Costituzionale. Padova: Cedam, 1993. p. 100).

18 "Ė noto che l'ant. 15 della legge n. $400 / 1988$ stabilisce, tra l'altro, che il Governo no púo,

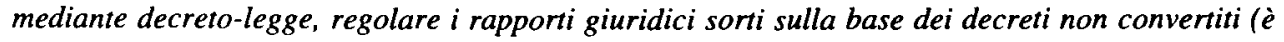
l'ultimo comma dell'art. 77 della Costituzione che affida alle Camere tale compito: anche se va riconosciuto che un'applicazione lenta della previsione costituzionale può determinare efletti danosi per $i$ soggetti che, in ossequio alla lege, abbiano ottemperato alle disposizioni del decreto)". (Riflessioni in tema di decretilegge non convertiti. In BAUDREZ, Maryse et alli. I decreti-legge non convertiti. Milano, Giuffrè, 1996. p. 137-138). Para ser mais preciso, é bom dizer que, na Itália, demais da Constituição, o art. 15, inciso segundo, letra $d$, da Lei 400/88, tentando racionalizar a matéria, obsta que um decreto-legge regule as relações produzidas por decreto-legge não convertido. 19 "Ugualmente pacifica appare Ia preclusione per i decreti a sanare gli effetti sorti sulla base di precedenti decreti non convertiti, stante la esplicita riserva alle "Camere [di] regolare con legge i rapporti giuridici sorti sulla base dei decreti-legge non convertiti". (L'abuso del decreto-legge. Roma, Cedam, 1997. p. 535). 
jurídicas surgidas com base em um decreto-lei não convertido seja disposta por um outro decreto-lei, mas deste modo aquela não faz outra coisa que reforçar uma norma já deduzida da complexa disciplina predisposta pelo art. 77"20.

As lições da doutrina produziram forte eco perante a Corte Constitucional, que vedou a chamada reiterazone "a catena", conforme exemplifica a Sentenza 544, de 14 de dezembro de 1989, ou seja, que a convalidação tivesse lugar mediante os sucessivos decreti-legge produzidos em cadeia. Embora essa não tenha sido a questão principal do debate, da referida decisão é encontradiça a seguinte passagem: "Não pode haver dúvida que o decreto-lei seja uma fonte incompetente para regular as relações jurídicas surgidas com base em precedentes decretos não convertidos e que, em geral, uma disposição de um decreto-lei, a qual estabelece um termo dos seus efeitos, a partir da data da entrada em vigor do precedente decreto não convertido, possa suscitar sérias dúvidas sobre a correção da conduta do Governo à luz do art. 77 Cost. E 151. 400/1988" 21.

Mais recentemente, por ocasião de questão incidental de legitimidade constitucional do art. $2^{\circ}$ do Decreto-legge 238, de 21 de junho de 1995, que modificara o art. $8^{\circ}$ do Código de Processo Civil italiano, suscitada pelo Pretor de Verona, a Corte Constitucional, rejeitando-a na Sentenza 84, de 21 de fevereiro de 1996, relatada pelo Juiz Renato Granata, expôs: “E esta Corte já afirmou, em geral (sentença $n$. 243 de 1985), que 'através da técnica da sanatória' 'o terceiro inciso do art. 77 da Constituição habilita o legislador a ditar uma regulamentação retroativa das relações, sem por outros limites a não ser aqueles representados pelo respeito das outras normas e princípios constitucionais'" 22 . Prosseguindo, acentuou que o conteúdo da disposi-

20 "La disposizione in esame può essere intesa nel senso che essa vieti che la disciplina dei rapporti giuridici sorti sulla base di un decreto non convertito sia disposta con un altro decreto legge, ma in questo modo essa non fa altro che ribadire una norma già desumibile dalla disciplina complessiva predisposta dall'art. 77'. (La legge di conversione del decreto legge. Pádua: CEDAM, 1989. p. 332). No mesmo sentido, consultar ainda: Paolo Biscaretti di Rufia (Diritto Costituzionale. 15. ed. Nápoles: Jovene Editore, 1989. p. 569), Livio Paladin (Diritto Costituzionale. 3. ed. Milão: CEDAM, 1998. p. 198), Fausto Cuocolo (Principi di Diritto Costituzionale. Milão: Giuffrè Editore, 1996. 163), Giuseppe de Vergottini (Diritto Costituzionale. Pádua: CEDAM, 1997. p. 209). Na doutrina francesa, merecedora de destaque Maryse Baudrez, professora da Universidade de Toulon, às voltas com a análise da figura do art. 77 da Constituição italiana (Décrets-lois réitérés en Italie: l'exaspération mesurée de la Cour constitutionnelle. Revie Française de Droit Constitucionnel, $n^{\circ} 32, p$. $751,1997)$, torna manifesta a compulsoriedade do pensamento aqui exposto ao depois da Sentenza 84/1996 da Corte Constitucional.

21 "Non vi può esser dubbio che il decreto-legge sia una fonte incompetente a regolare $i$ rapporti giuridici sorti in base a precedenti decreti non convertiti e che, in generale, una disposizione di un decreto-legge la quale stabilisca una decorrenza dei propri effetti a partire dalla data di entrata in vigore del precedente decreto non convertido possa suscitare seri dubbi circa la correttezza dell'operato del Governo alla luce dei citati art. 77 Cost. e 15 1. 400/1988'. (Apud Franco Modugno e Alfonso Celloto. Rimedi all'abuso del decreto-legge. Giurisprudenza Costituzionale, ano XXXIX, $n^{\circ} 5$, p. 3.242 , set./out. 1994)

22 "E questa Corte già affermato, in generale (sentenza n. 243 del 1985), che "traverso la tecnica della sanatoria" "il terzo comma dell'art. 77 da Costituzione abilita il legislatore a dettare una 
ção não convertida, embora reproduzido em um ou mais decretos-lei sucessivos até a sua conversão em lei, fora atingido pela cláusula de salvaguarda, contida naquela, a qual tem a função de repristinar, segundo uma opção atribuída à avaliação discricionária do Parlamento, uma continuidade normativa, fazendo remontar no tempo a nova disciplina à originária disposição não convertida, com a consolidação dos efeitos desta. Restou elucidada, de maneira tácita, mas ao mesmo tempo suficientemente óbvia, que tal atribuição constitui exclusividade do Poder Legislativo, não se admitindo a interferência substitutiva do Governo.

Fazendo-se incidir tais ensinamentos ao modelo brasileiro, adaptados à pequena diferença introduzida pelo art. 62, parágrafo único, parte final, da Lei Máxima, tem-se, da mesma forma, a total impossibilidade de medida provisória disciplinar as relações jurídicas surgidas sob o efêmero império temporal de medida provisória não convertida em lei.

A razão para tanto não deveria dispensar maiores comentários, em virtude da clareza da dicção constitucional. O Constituinte de 1988 serviu-se, no dispositivo acima mencionado, do binômio Congresso Nacional, órgão que, na redação mais límpida impossível do art. 44, caput, da Constituição Federal, tem a seguinte configuração: "Art. 44. O Poder Legislativo é exercido pelo Congresso Nacional, que se compõe da Câmara dos Deputados e do Senado Federal". Daí se vê que a medida provisória, cuja competência para a sua edição pertence ao Presidente da República, é inteiramente inidônea para o fim sob discussão.

Visto isso, não se pode deixar de considerar que a grande maioria dos tribunais e juízes, apesar da não existência de previsão de eficácia vinculante das decisões do Supremo Tribunal Federal e do Superior Tribunal de Justiça, em matéria constitucional e legal, respectivamente, vem adotando, no desate dos litígios que the são submetidos, as orientações de ditas Cortes, a fim de evitar desagradáveis incoerências na aplicação do ordenamento jurídico, as quais, em algumas situações, têm sido capazes de gravemente maltratar o princípio da isonomia.

A despeito dessa postura, estou em que a observância dos precedentes, emanados das Cortes Superiores, pelos juízes e tribunais inferiores, não é tal que seja capaz de transformar estes na condição de meros autômatos na aplicação das orientações firmadas por aquelas. Absolutamente. Nos países, cuja cultura jurídica é fortemente marcada pela doutrina do precedente, assoma possível ao julgador distanciar-se, motivadamente, da orientação naquele assentada.

Invoque-se a consagrada opinião de Charles D. Cole, ao anotar que quando “o juiz de primeira instância se depara com a aplicação de um precedente anterior que tenha sido muito desgastado com o passar do tempo ou por outros casos precedenciais deixando claro que o precedente deveria ser revogado se o caso fosse submetido à Corte recursal própria, ele pode se recusar a seguir o precedente" ${ }^{23}$. Corroborando

regolamentazione retroattiva dei rapporti", senza porre "altri limiti se non quelli rappresentati dal rispetto delle altre norme e principi costituzionali". (Disponível em www.giurcost.org/decisioni. Acesso em 09-03-01).

23 Precedente judicial - a experiência americana. Revista de Processo, a. 23, n. 92, out./dez., 1998. p. 80. 
esse entendimento, demasiado pertinente o ensinamento de João de Castro Mendes, no sentido de "que os precedentes e regras devem ser seguidos, a não ser que sejam abertamente absurdos ou injustos" 24 .

Atento a tais pontos de vista, de inegável valia, demonstrando que a vinculação precedencial não é uma província estranha a exceções, manifesto-me pela razoabilidade da não observância da orientação firmada na ADINMC 2.25]-DF, a qual, a despeito de promanada do sábio descortino da Excelsa Corte, investe, de maneira flagrante, não só em detrimento da letra, mas sobretudo do espírito do art. 62, parágrafo único, parte final, da Constituição vigente.

Não se diga que o assunto é de somenos importância. Pelo contrário, é capaz de assumir, nos casos concretos, grande interesse, no escopo do resguardo do postulado da segurança jurídica, principalmente quando se observa em nosso país forte tendência legislativa, centrada no uso da medida provisória como instrumento de restrição de direitos. Alguns exemplos, versados nas linhas abaixo, são bastante esclarecedores.

O art. 192, I e II, da Lei 8.112/90, assegurava ao servidor que contasse com tempo para aposentar-se com proventos integrais o direito, na inatividade, à remuneração do padrão da classe imediatamente superior àquela em que se encontrava posicionado. Caso aquele já estivesse posicionado na última classe, faria jus à diferença entre a remuneração desta e da antecedente.

Em 11.10.96, fora editada a Medida Provisória 1.522, revogando, às expressas, o art. 192 da Lei 8.112/90. Ao depois de várias reedições, fora transformada na Lei 9.527/97, que manteve a ab-rogação do citado dispositivo. À vista disso, indaga-se qual o termo a quo da alteração jurídica? Poderá ser considerada a data do início da cadeia das medidas provisórias, todas reiteradas no trintídio constitucional, o que recairia no dia 11.10.69 Adotando-se a concepção acolhida na ADINMC 2.251-DF, a resposta inelutavelmente seria afirmativa.

Todavia, não se pode olvidar que a Lei $9.527 / 97$, ao converter em lei a extinção da aludida vantagem funcional, enunciara, no seu art. 16, apenas a convalidação dos efeitos produzidos pelas Medidas Provisórias 1.573/13, de 27.10.97, e 1.595/14, de 10-11-97. Quanto às medidas provisórias anteriores, $o$ ato de convalidação teve sua origem em medida provisória posterior, como a hipótese vivenciada pela própria Medida Provisória 1.595-14, cujo art. 15 diz ficarem convalidados os atos praticados com base na Medida Provisória 1.573-13/97.

Diferentemente, com a leitura do art. 62, parágrafo único, parte final, da CF cuja finalidade outra não fora senão a de reservar ao Parlamento a missão de controlar a legislação governamental, a fim de que o desvirtuamento desta não afetasse o equilíbrio entre os poderes estatais -, somente pode ser reputada extinta a vantagem do art. 192 da Lei $8.112 / 90$ a contar de 27.10 .97 e não de 11.10.96, porquanto aquele assinala o marco, a partir do qual a eficácia da longa cadeia de medidas provisórias não convertidas tivera a sua convalidação operada mediante atividade do Congresso

24 Direito comparado. ed. rev. e atual. Lisboa: Associação Acadêmica da Faculdade de Direito Lisboa. 1982-1983, p. 207. 
Nacional, calcada no art. 16 da Lei 9.527/97. Daquela data, então, é que, validamente, poderá operar seus efeitos a restrição estipendiária imposta aos funcionários públicos da Administração Federal Direta, Autárquica e Fundacional.

De concluir, portanto, que os servidores públicos federais que tenham reunido os requisitos necessários à aposentação, por tempo de serviço, com proventos integrais, até 27.10.97, poderão ser beneficiados pela vantagem do art. 192, I e II, da Lei 8.112/90. Indevido será pensar, pelas razões expostas, que a extinção de tal beneficio pudera ter início em 11.10.96.

O mesmo sucedeu com a licença-prêmio por assiduidade, substituída pela licença para capacitação. Neste ponto, a agressão à segurança jurídica restou mais evidente, uma vez a Lei $9.527 / 97$, no seu art. $7^{\circ}$, ter resguardado o direito adquirido dos servidores à sua contagem até 15.10 .96 , quando a extinção da vantagem, como já salientado linhas atrás, somente ocorrera em 27.10.97, data da Medida Provisória 1.573-13, primeira a possuir os seus efeitos salvaguardados na forma do art. 62, parágrafo único, parte final, da Lei Magna. Idêntica sorte se estende à forma de pagamento de substituições, em face de mudança impostá ao art. 38 da Lei 8.112/90. Não se pense que essa viciada praxe legislativa está circunscrita à limitação dos direitos funcionais, mas poderá, de igual maneira, ser verificada por ocasião, das restrições de outros direitos subjetivos, efetuados pela via da medida provisória.

Disso tudo, assoma importante concluir que, tendo em vista a consentida reedição sem peias de medida provisória haver quase conduzido a uma absorção do poder de legislar pelo Presidente da República, com grave prejuízo à separação de poderes, torna-se necessário que tal prática degenerativa seja minimizada, a fim de que pelo menos reste incólume a segurança jurídica, cuja tutela não dispensa que a convalidação dos efeitos das anteriores medidas não convertidas seja efetuada de acordo com os precisos termos do art. 62, parágrafo único, parte final, da Constituição.

Como a nossa experiência em tema de legislação pelo Executivo é bastante recente, haja vista que os modelos constitucionais pretéritos foram desenvolvidos sob clima político de exceção, resta-nos esperar que a Suprema Corte não dê por encerrada a discussão do assunto com a ADINMC 2.251 - DF, de sorte a que, no futuro, aquele possa ser reexaminado, com a prevalência das opiniões vencidas dos Ministros Marco Aurélio e Celso de Mello 25 .

25 De salientar que o uso abusivo de medidas provisórias foi passível de censura pelo Min. Celso de Mello, em despacho no RE 239.286 (RDA 219/323-329). 